\title{
FIRE EFFECT ON THE SEASONAL FOREST STRUCTURE IN THE CERRADO BIOME
}

\author{
Iokanam Sales Pereira ${ }^{1 *}$, Francine Neves Calil ${ }^{2}$, Thalles Oliveira Martins ${ }^{3}$, Carlos de Melo e Silva-Neto ${ }^{4}$, Jéssyca \\ Barroso Borges ${ }^{5}$, Fábio Venturoli ${ }^{2}$, Lucas Henrique Oliveira ${ }^{5}$, Pedro Vilela G. Barbosa ${ }^{6}$, \\ Ana Carolina Freitas Xavier ${ }^{7}$, Bruno Bastos Gonçalves ${ }^{8}$ \\ ${ }^{1 *}$ National Institute for Amazon Research, Post Graduate Program in Tropical Forest Science, Manaus, Amazonas, Brazil - \\ iokanam.eng@gmail.com \\ ${ }^{2}$ Federal University of Goiás, School of Agronomy, Goiânia, Goiás, Brazil - fncalil@ gmail.com; fabioventuroli@ gmail.com \\ ${ }^{3}$ University of Brasília, Post Graduate Program in Forest Science, Brasília, Distrito Federal, Brazil - thallesflorestal@ hotmail.com \\ ${ }^{4}$ Federal Institute of Education Science and Technology, City of Goiás, Goiás, Brazil - carloskoa@ gmail.com \\ ${ }^{5}$ Federal University of Goiás, Graduation in Forest engineering, Goiânia, Goiás, Brazil - jess.solos@gmail.com; \\ lucashenrique19915@gmail.com \\ ${ }^{6}$ Master in Plant Biodiversity Federal University of Goiás - Goiânia, Goiás - pvgb@ florestal.eng.br \\ ${ }^{7}$ Master in Environmental Engineering from the Federal Technological University of Paraná (Campus Londrina), Paraná, Brazil - \\ anacarolinaf.xavier@gmail.com \\ ${ }^{8}$ Doctorate in Aquaculture, Unesp, Botucatu, São Paulo, Brazil - goncalves.b.b@gmail.com
}

Received for publication: 18/02/2016 - Accepted for publication: 29/09/2016

\begin{abstract}
There are few studies on the effects of fire on the seasonal semideciduous forest of the Cerrado region. This study aimed to assess the effect of fire on Semideciduous forest fragments located in the Altamiro Moura Pacheco State Park (AMPSP). The study area is located in the central state of Goiás. A total of 10 plots $(50 \mathrm{x}$ $20 \mathrm{~m} ; 1,000 \mathrm{~m}^{2}$ ) were drawn in the remaining forests seeking to portray two areas: area which underwent forest fire (burned area; B) and unburned area (unburned; UB). A total of 771 individuals with DBH ( $\geq 5 \mathrm{~cm}$ ) were identified. A total of 303 individuals were recorded in the burned area (B), comprising 28 families, 41 genera and 47 species, while the unburned area (UB) had 468 individuals comprising 25 families, 43 genera and 50 species. The species Anadenanthera colubrina (Vell.) Brenan, Emmotum nitens (Benth.), Zanthoxylum rhoifolium Lam, Tapirira guianensis Aubl., Myracrodruon urundeuva Allemão and Luehea candicans Mart. had the highest Importance Value Index (IVI) values and occur in both areas. The percentage of dead trees differed between the areas, where the burned area had a mortality of $12.69 \%$ and the unburned area of $7.29 \%$ in regards to the number of individuals. Density per plot was the only parameter that differed between the areas, where the burned area (B) had the lowest values. The fire affected all diameter classes, demonstrating the fragility of this vegetation type in regards to fire. The fire had a greater effect on trees in the smaller diameter classes, reducing the frequency of individuals in the burned area and changing height distribution, which may have favored the establishment of lianas and invasive species.

Keywords: Abundance; richness; tree community; forest fires.
\end{abstract}

\section{Resumo}

Efeito do fogo na estrutura de floresta estacional no Bioma Cerrado. A área de estudo está localizada na região central do estado de Goiás. Foram sorteadas 10 parcelas, de $50 \times 20 \mathrm{~m}\left(1.000 \mathrm{~m}^{2}\right)$, nos remanescentes florestais buscando amostrar duas áreas: área que sofreu incêndio florestal (Q) e área não queimada (NQ). Foram identificados 771 indivíduos com DAP ( $\geq 5 \mathrm{~cm}$ ). Na área queimada (Q) foram levantados 303 indivíduos distribuídos em 28 famílias, 41 gêneros e 47 espécies. Já na área não queimada (NQ) foram amostrados 468 indivíduos, distribuídos em 25 famílias, 43 gêneros e 50 espécies. As espécies que apresentaram os maiores valores de Índice de Valor de Importância (IVI) e que ocorrem em ambas as áreas foram Anadenanthera colubrina (Vell.) Brenan, Emmotum nitens (Benth.), Zanthoxylum rhoifolium Lam, Tapirira guianensis Aubl., Myracrodruon urundeuva Allemão e Luehea candicans Mart.. A porcentagem de árvores mortas diferenciou entre as áreas, sendo que na queimada apresentou 12,69\% e na não queimada $7,29 \%$, do número total de indivíduos. Dos parâmetros analisados, o único que apresentou diferença estatística significativa foi a densidade de indivíduos por parcela, onde a área queimada (Q) apresentou os menores valores. $\mathrm{O}$ fogo agiu sobre todas as classes de diâmetro, demonstrando assim a fragilidade desta fitofisionomia para com o fogo. Os maiores efeitos do fogo foram sobre as árvores com classes de menor diâmetro, diminuindo a frequência de indivíduos na área queimada e modificando a distribuição de altura, o que pode ter facilitado o estabelecimento de lianas e espécies invasoras.

Palavras-chave: Abundância; riqueza; comunidade arbórea; incêndios florestais.

FLOREST A, Curitiba, PR, v. 46, n. 4, p. 499 - 508, out. / dez. 2016.

Pereira, I. S. et al.

ISSN eletrônico 1982-4688

DOI: $10.5380 /$ rf.v46i3.45277 


\section{INTRODUCTION}

The Brazilian Cerrado region occupies about $25 \%$ of Brazil with an original area of approximately 203 million $\mathrm{km}^{2}$ (RIBEIRO; WALTER, 2008), of which only 47\% remains (about 103 million $\mathrm{km}^{2}$ ) (BRASIL, 2014). Low humidity conditions at a certain time of the year (dry season), in addition to other factors such as humidity of the fuel, presence of invasive species, relief and vegetation type, may favor the spread of forest fires in the Cerrado (FREIRE et al., 2002 TORRES, 2006). The fire acts directly on the plant communities and may modify the floristic composition, forest structure, plant recruitment (COCHRANE; SCHULZE, 1999) and reduce tree density per area (LIMA, et al., 2009).

Effects of fire in the Cerrado biome are regarded as a determining factor for the structure and functioning of the biome (SIMON et al., 2009). The occurrence of changes in plant communities after the passage of fire is strictly related to three main factors: (i) the number of individuals present in the area, (ii) the arrangement of these individuals in the area and (iii) the specific growth of each species (LOPES et al., 2009).

In this work, we hypothesized that the occurrence of the fire changes the community structure in Semideciduous Seasonal Forest Cerrado. Therefore, the objective of this study was to assess the effect of fire occurrence on the tree community structure of the Semideciduous Seasonal Forest in the Altamiro de Moura Pacheco State Park (AMPSP) using floristic surveys of the burned and unburned areas of the Park.

\section{MATERIAL AND METHODS}

\section{Characterization of the study area}

This study was carried out in the Altamiro de Moura Pacheco State Park (AMPSP), located between the geographic coordinates $16^{\circ} 30^{\prime}-16^{\circ} 35^{\prime} \mathrm{S}$ and $49^{\circ} 07^{\prime}-49^{\circ} 13^{\prime} \mathrm{W}$, Goias state. The park is a full protection conservation unit established by the Law num. 11.878 on December 30 1992, with a current area of 2,132 hectares and prevailing vegetation comprising dry forest, riparian forest, gallery forest, cerrado strict sense, Cerradão (Higth cerrado) and capoeira (Medium secondary sucession vegetation), in addition to some areas covered with pastures (SEMARH, 2015).

The climate of the region is Aw according to the Koppen classification, i.e., Sub-humid savannah with two distinct seasons: the rainy and dry periods (PEEL et al., 2007). The rainy period occurs in the summer (October to April), and the dry period in the winter (May to September, where July and August are the driest months).

The average temperature of the coldest month is above $18^{\circ} \mathrm{C}$. Precipitation is greater than $750 \mathrm{~mm}$ per year, reaching at maximum 1,800 mm (CARDOSO, 2015). The prevailing soils are Oxisols (Red and Dusky Red Latosols), and Red-Yellow Argisols according to the Brazilian System of Soil Classification (EMBRAPA, 2013). The topography varies from slightly to sharply steep (SEMARH, 2015).

\section{Floristic data collection}

The first area in which the survey of the species was carried out was located near the headquarters of the Altamiro Moura Pacheco State Park, an area that was burned (B) in 2013. The second area did not suffer the passage of fire (unburned area; UB). A total of five plots of 0.1 ha $(20 \times 50 \mathrm{~m})$ were established in each area (FELFILI et al., 1994). The inventory was conducted between the months of February to April 2015.

The trees with circumference at breast height equal to or above $15.7 \mathrm{~cm}$ (or diameter at breast height $\mathrm{DBH} \geq 5 \mathrm{~cm}$ ) were measured in each plot using a graduated tape $(\mathrm{cm})$. All branches of a single tree, and all the bifurcations below the height of $1.30 \mathrm{~m}$ were measured separately being realized average values for branches.

The plots were temporarily marked with a barricade tape, with all the tree specimens included in the sample being identified with aluminum platelets in a sequential order. The geographical coordinates were obtained in the center of each plot using a Global Positioning System (GPS).

The species not identified by the survey team were collected using a trimmer, and stored in plastic bags to subsequently be sent to the Allometry and Forest Inventory laboratory (Laboratório de Alometria e Inventário Florestal; LAIF) of the Federal University of Goiás. The angiosperms classification system of the Angiosperm Philogeny Group III (APG III, 2009) was used.

\section{Phytosociological analysis}

The indexes that show the horizontal structure of vegetation (i.e., density, dominance, frequency and the coverage index - CI) were compared to assess changes in species composition and community structure. The Soresen index (Ss - Eq1) was used to calculate the similarity among sites and the Pielou index ( $J-E q 2)$ to assess the distribution of individuals in regards to the species (VENTUROLI et al., 2016).

$$
\text { Ss }=2 \mathrm{c} / \mathrm{a}+\mathrm{b} \quad(\mathrm{Eq} 1)
$$


Where $\mathrm{a}=$ number of species occurring in part 1 or 1 community; $\mathrm{b}=$ number of species that occur in the portion 2 or 2 community; $\mathrm{c}=$ number of common species in two installments or communities

$$
\mathrm{J}=\mathrm{H}^{\prime} / \text { Hmáx }
$$

Where $\mathrm{H}^{\prime}=$ Shannon-Weaver diversity index; $\operatorname{Hmax}=\operatorname{Ln}(\mathrm{S}) ; \mathrm{S}=$ number of total species sampled.

\section{Statistical Analysis}

The nonparametric Mann-Whitney test was used with a 95\% significance level to compare the studied areas (burned and unburned areas). A box-plot with the quantiles, maximum and minimum values and the median of each area analyzed was built for the variable which significantly differed between the areas (number of individuals).

Species occurrence pattern and the number of individuals in the burned (B) and unburned areas (UB), were evaluated separating the different groups and discriminating the number of individuals of each species found. Then, a principal component analysis was carried out.

\section{Height and diameter structure}

The frequency distribution among the diameter and height classes were calculated and represented as histograms for the horizontal and vertical characterizations of the fragments sampled. The amplitude of the diameter classes was defined in $5 \mathrm{~cm}$ and of the height classes in $2 \mathrm{~m}$ for comparison purposes. These amplitude definitions follow Haidar (2008) and Souza et al., (2012) in studies carried out in a Semideciduous Seasonal Forest (SSF).

\section{RESULTS}

A total of 303 individuals were sampled in the burned area (B), comprising 27 families, 43 genera and 48 species. In the unburned areas (UB), 468 individuals were sampled, encompassing 24 families, 44 genera and 50 species. The total sampling (both areas) includes 68 tree species distributed among 56 genera and 31 botanical families. The species Anadenanthera colubrina (Vell.) Brenan (angico), Emmotum nitens (Benth.) (pau-sobre), Zanthoxylum rhoifolium Lam.(mamica-de-porca), Tapirira guianensis Aubl.(pombeiro), Myracrodruon urundeuva Allemão (aroeira) and Luehea divaricata Mart. (açoita-cavalo) had the highest importance values (IVI) and occurred in both areas.

The Fabaceae family had the highest species richness in both areas, with 13 species and 11 genera (three species and three genera of the subfamily Caesalpinioideae, seven species and five genera of Mimosoideae, and three species and three genera of Papilionoideae). The second most species rich families were Apocynaceae with five species and one genus and Malvaceae with five species and five genera. Anacardiaceae, Combretaceae Sapindaceae, Meliaceae and Myrtaceae were represented by three species and three genera each. Bignoniaceae had three species and two genera, while Annonaceae had three species and one genus.

The families Arecaceae and Salicaceae, had two species and two genera, and the family Lauraceae had two species and one genus. The 18 remaining families, namely Araliaceae, Boraginaceae, Burseraceae, Celastraceae, Ebenaceae, Euphorbiaceae, Icacinaceae, Lecythidaceae, Melastomataceae, Opiliaceae, Polygonaceae, Proteaceae, Rhamnaceae, Rubiaceae, Rutaceae, Sapotaceae, Urticaceae and Vochysiaceae, were represented by a single species each. The species Anadenanthera colubrina (angico), Piptadenia gonoacantha (pau-jacaré), Platypodium elegans (jacarandá-do-campo), Zanthoxylum rhoifolium (mamica-de-porca) and Myrcia rostrata DC (Guamirim) were highlighted among the recorded species. In relation to statistical analysis, just the individual density parameter showed a significant difference between the plots of the two studied areas (Table 1).

Table 1. Average of the parameters analyzed per study area, burned area (B) and unburned area (UB), in the Altamiro Moura Pacheco State Park, state of Goiás. The parameters represented by $J$ and $S s$ are the Pielou and Soresen indexes, respectively.

Tabela 1. Média dos parâmetros analisados por área de estudo, area queimada (B) e área não queimada (UB), no Parque Estadual Altamiro Pacheco, estado de Goiás, Os parâmetros apresentados por $J$ e $S s$ são os indices de Pielou e Soresen, respectivamente.

\begin{tabular}{|c|c|c|c|c|c|c|c|}
\hline Área & NF & NI & $\mathbf{N E}$ & $\mathbf{A H}$ & $\mathbf{B A}$ & $\mathbf{J}$ & Ss \\
\hline B & $13.2 \pm 2.77 \mathrm{a}$ & $60.6 \pm 17.98 \mathrm{a}$ & $20.4 \pm 4.92 \mathrm{a}$ & $10.17 \pm 1.89 \mathrm{a}$ & $2.52 \pm 1.22 \mathrm{a}$ & 0.42 & \multirow{2}{*}{0.58} \\
\hline UB & $15.6 \pm 3.04 \mathrm{a}$ & $93.6 \pm 20.93 \mathrm{~b}$ & $26 \pm 4.52 \mathrm{a}$ & $8.90 \pm 0.58 \mathrm{a}$ & $2.11 \pm 0.58 \mathrm{a}$ & 0.58 & \\
\hline
\end{tabular}

Subtitle: NF- number of families, NI= number of individuals, $\mathrm{NE}=$ number of species, $\mathrm{AH}=$ average height, $\mathrm{BA}=\mathrm{basal}$ area, $\mathrm{J}=\mathrm{Pielou}$ index, $\mathrm{Ss}=$ Soresen index. 
The absolute density of the unburned area (UB) was 936 ind.ha $^{-1}$ and the basal area (dominance) was $21.42 \mathrm{~m}^{2} . \mathrm{ha}^{-1}$, with $7.69 \%$ of the total density being of standing dead trees ( 72 individuals). The absolute density of the burned (B) area was 606 ind.ha ${ }^{-1}$ and the basal area was $25.24 \mathrm{~m}^{2} \cdot \mathrm{ha}^{-1}$, with $12.21 \%$ of the total density being standing dead trees (74 individuals).

The Soresen index calculated for this study was 0.58 , and the Pielou index $(\mathrm{J})$ was 0.42 and 0.58 for the burned and unburned area, respectively. A higher concentration of individuals UB areas were recorded in the smaller diameter classes. In addition, frequency of occurrence decreases as diameter class increases, showing a "reverse J" shaped distribution (Figure 1).

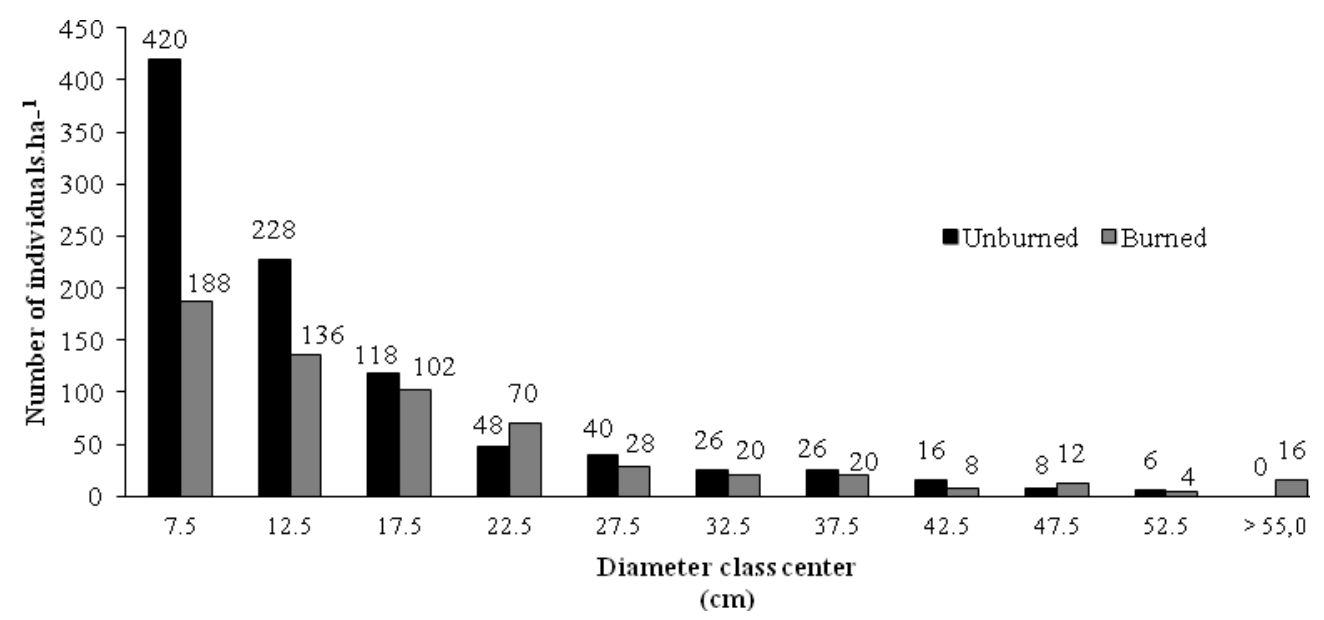

Figure 1. Number of individuals per diameter class $(\mathrm{DBH}>5 \mathrm{~cm})$ register in the study areas (burned or unburned) of seasonal semideciduous forest of the Altamiro de Moura Pacheco State park, Goiás.

Figura 1. Número de indivíduos por classe de diâmetro (DAP $>5 \mathrm{~cm}$ ) registrados nas áreas de estudo (queimadas e não queimadas) de floresta estacional semidecidual do Parque Estadual Altamiro Pacheco, Goiás.

The distribution of individuals in height classes tends to statistical normality in the unburned area, with a higher frequency of individuals in the smaller size classes $(<10 \mathrm{~m})$. The distribution of height classes in burned area had an asymmetric distribution, with the highest concentration of individuals in the smaller height classes (Figure 2).

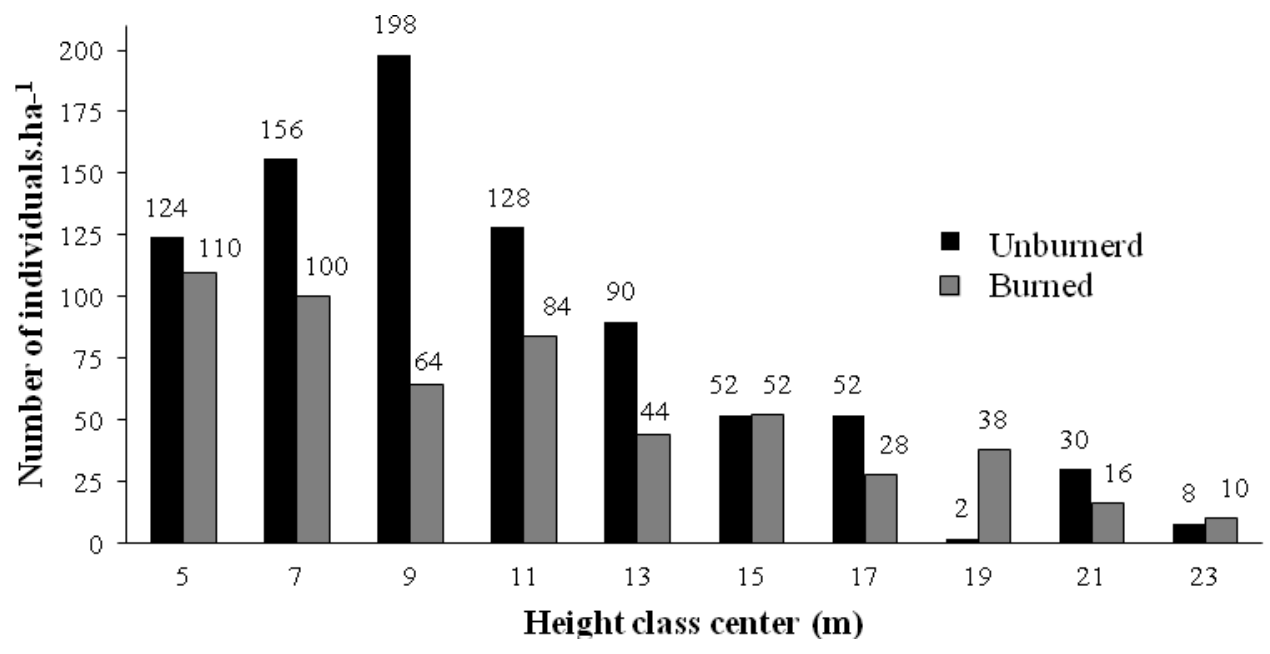

Figure 2. Frequency distribution of tree individuals in height classes $(\mathrm{DBH}>5 \mathrm{~cm})$ of the burned and unburned fragment of seasonal semideciduous forest of the Altamiro de Moura Pacheco State Park, Goiás.

Figura 2. Frequência de distribuição dos indivíduos arbóreos em classes de altura (DAP>5 cm) do fragmento queimado e não queimado da floresta estacional semidecidual do Parque Estadual Altamiro Pacheco, Goiás. 
The ten highest IVIs in the B area were, in a descending order: Anadenanthera colubrina (Vell.) Brenan, Hymenaea courbaril L., Platypodium elegans Vogel, Ocotea spixiana (Ness) Mez, Emmotum nitens (Benth.) Miers, Luehea candicans Mart., Myracrodruon urundeuva Allemão, Zanthoxylum rhoifolium Lam., Tapirira guianensis Aubl. and Astronium fraxinifolium Schott, adding up to $49.3 \%$ of the total IVI of the B tree community. The phytosociological parameters the tree community of the burned (B) and unburned (UB) areas in the Seasonal forest of the Altamiro de Moura Pacheco State Park, Goiás are presented in table 2.

Table 2. Phytosociology parameter of the tree community of the burned (B) and unburned (UB) areas in the Seasonal forest of the Altamiro de Moura Pacheco State Park, Goiás. Phytosociological parameters arranged in descending order of IVI in relation the unburned area.

Tabela 2. Parâmetro fitossociológico da comunidade arbórea de áreas queimadas (B) e não queimadas (UB) na floresta sazonal do Parque Estadual Altamiro Pacheco, Goiás. Parâmetros fitossociológicos dispostos em ordem de IVI descendente em relação a area não queimada.

\begin{tabular}{|c|c|c|c|c|c|c|c|c|c|c|c|c|c|c|}
\hline \multirow[b]{2}{*}{ Species } & \multicolumn{12}{|c|}{ Unburned (NB) } & \multicolumn{2}{|c|}{ Burned (B) } \\
\hline & AD & RD & $\mathbf{A F}$ & RF & ADo & RDo & IVI & AD & RD & AF & RF & ADo & RDo & IVI \\
\hline Anadenanthera colubrina & 132 & 14,1 & 100 & 3,85 & 8,88 & 41,4 & 59,43 & 78 & 12,9 & 100 & 4,90 & 6,57 & 26,00 & 43,78 \\
\hline Árvores mortas & 72 & 7,69 & 100 & 3,85 & 1,21 & 5,64 & 17,18 & 74 & 12,2 & 100 & 4,90 & 3,17 & 12,56 & 29,67 \\
\hline Piptadenia gonoacantha & 46 & 4,91 & 100 & 3,85 & 1,47 & 6,88 & 15,64 & 18 & 2,97 & 60 & 2,94 & 0,45 & 1,77 & 7,68 \\
\hline Emmotum nitens & 70 & 7,48 & 100 & 3,85 & 0,67 & 3,11 & 14,43 & 16 & 2,64 & 100 & 4,90 & 1,14 & 4,52 & 12,07 \\
\hline Zanthoxylum rhoifolium & 68 & 7,26 & 100 & 3,85 & 0,65 & 3,03 & 14,14 & 26 & 4,29 & 80 & 3,92 & 0,35 & 1,39 & 9,60 \\
\hline Myrcia rostrata. & 60 & 6,41 & 100 & 3,85 & 0,53 & 2,47 & 12,73 & 4 & 0,66 & 40 & 1,96 & 0,01 & 0,06 & 2,68 \\
\hline Tapirira guianensis & 46 & 4,91 & 100 & 3,85 & 0,75 & 3,52 & 12,28 & 20 & 3,30 & 80 & 3,92 & 0,37 & 1,46 & 8,68 \\
\hline Myracrodruon urundeuva & 20 & 2,14 & 80 & 3,08 & 1,20 & 5,61 & 10,82 & 18 & 2,97 & 100 & 4,90 & 0,51 & 2,01 & 9,89 \\
\hline Aspidosperma subincanum & 40 & 4,27 & 100 & 3,85 & 0,47 & 2,19 & 10,31 & 10 & 1,65 & 20 & 0,98 & 0,24 & 0,95 & 3,58 \\
\hline Luehea candicans & 50 & 5,34 & 80 & 3,08 & 0,33 & 1,53 & 9,95 & 30 & 4,95 & 60 & 2,94 & 0,64 & 2,55 & 10,44 \\
\hline Psidium sartorianum & 28 & 2,99 & 60 & 2,31 & 0,34 & 1,58 & 6,88 & 4 & 0,66 & 40 & 1,96 & 0,02 & 0,09 & 2,71 \\
\hline Astronium fraxinifolium & 14 & 1,50 & 60 & 2,31 & 0,66 & 3,06 & 6,86 & 22 & 3,63 & 40 & 1,96 & 0,72 & 2,83 & 8,42 \\
\hline Schefflera morototoni & 10 & 1,07 & 60 & 2,31 & 0,46 & 2,15 & 5,53 & 8 & 1,32 & 20 & 0,98 & 0,94 & 3,74 & 6,04 \\
\hline $\begin{array}{l}\text { Enterolobium } \\
\text { contortisiliquum }\end{array}$ & 8 & 0,85 & 60 & 2,31 & 0,49 & 2,30 & 5,46 & - & - & - & - & - & - & - \\
\hline Inga cylindrica & 12 & 1,28 & 60 & 2,31 & 0,28 & 1,32 & 4,90 & 8 & 1,32 & 40 & 1,96 & 0,07 & 0,28 & 3,56 \\
\hline Alibertia edulis & 16 & 1,71 & 60 & 2,31 & 0,16 & 0,75 & 4,77 & - & - & - & - & - & - & - \\
\hline Casearia sylvestris & 18 & 1,92 & 60 & 2,31 & 0,11 & 0,50 & 4,73 & 16 & 2,64 & 40 & 1,96 & 0,13 & 0,52 & 5,13 \\
\hline Tabebuia roseoalba & 10 & 1,07 & 80 & 3,08 & 0,12 & 0,55 & 4,69 & 6 & 0,99 & 20 & 0,98 & 0,14 & 0,56 & 2,54 \\
\hline Protium heptaphyllum & 16 & 1,71 & 60 & 2,31 & 0,12 & 0,57 & 4,59 & 4 & 0,66 & 20 & 0,98 & 0,03 & 0,10 & 1,74 \\
\hline Machaerium acutifolium & 14 & 1,50 & 60 & 2,31 & 0,14 & 0,67 & 4,47 & 4 & 0,66 & 20 & 0,98 & 0,10 & 0,39 & 2,03 \\
\hline Handroanthus serratifolius & 12 & 1,28 & 60 & 2,31 & 0,13 & 0,61 & 4,20 & 6 & 0,99 & 20 & 0,98 & 0,04 & 0,16 & 2,13 \\
\hline Guazuma ulmifolia & 12 & 1,28 & 60 & 2,31 & 0,11 & 0,51 & 4,10 & 2 & 0,33 & 20 & 0,98 & 0,10 & 0,39 & 1,70 \\
\hline Cedrela fissilis & 14 & 1,50 & 40 & 1,54 & 0,21 & 0,99 & 4,02 & 2 & 0,33 & 20 & 0,98 & 0,02 & 0,08 & 1,39 \\
\hline Bauhinia rufa & 10 & 1,07 & 60 & 2,31 & 0,09 & 0,44 & 3,81 & - & - & - & - & - & - & - \\
\hline Sapium glandulatum & 8 & 0,85 & 60 & 2,31 & 0,07 & 0,33 & 3,49 & - & - & - & - & - & - & - \\
\hline Bowdichia virgilioides & 8 & 0,85 & 60 & 2,31 & 0,07 & 0,32 & 3,48 & 4 & 0,66 & 40 & 1,96 & 0,02 & 0,10 & 2,72 \\
\hline Cariniana estrellensis & 12 & 1,28 & 40 & 1,54 & 0,12 & 0,55 & 3,37 & 4 & 0,66 & 40 & 1,96 & 1,17 & 4,63 & 7,25 \\
\hline Acronomia aculeata & 6 & 0,64 & 40 & 1,54 & 0,17 & 0,78 & 2,96 & - & - & - & - & - & - & - \\
\hline Casearia rupestres & 10 & 1,07 & 40 & 1,54 & 0,05 & 0,25 & 2,86 & - & - & - & - & - & - & - \\
\hline Cupania vernalis & 8 & 0,85 & 40 & 1,54 & 0,09 & 0,40 & 2,79 & 4 & 0,66 & 20 & 0,98 & 0,03 & 0,12 & 1,76 \\
\hline Aspidosperma discolor & 8 & 0,85 & 40 & 1,54 & 0,05 & 0,25 & 2,64 & - & - & - & - & - & - & - \\
\hline Hymenaea courbaril & 4 & 0,43 & 40 & 1,54 & 0,11 & 0,51 & 2,48 & 18 & 2,97 & 60 & 2,94 & 3,36 & 13,32 & 19,23 \\
\hline Platypodium elegans & 4 & 0,43 & 40 & 1,54 & 0,06 & 0,28 & 2,24 & 40 & 6,60 & 80 & 3,92 & 0,81 & 3,20 & 13,72 \\
\hline Copaifera langsdorffii & 6 & 0,64 & 20 & 0,77 & 0,16 & 0,74 & 2,15 & 8 & 1,32 & 60 & 2,94 & 0,30 & 1,17 & 5,44 \\
\hline Roupala montana & 4 & 0,43 & 40 & 1,54 & 0,03 & 0,15 & 2,12 & - & - & - & - & - & - & - \\
\hline Ocotea spixiana & 4 & 0,43 & 40 & 1,54 & 0,03 & 0,13 & 2,10 & 30 & 4,95 & 100 & 4,90 & 0,64 & 2,53 & 12,38 \\
\hline Albizia niopoides & 6 & 0,64 & 20 & 0,77 & 0,12 & 0,55 & 1,96 & 2 & 0,33 & 20 & 0,98 & 0,02 & 0,09 & 1,40 \\
\hline Xylopia sericea. & 6 & 0,64 & 20 & 0,77 & 0,11 & 0,50 & 1,91 & 14 & 2,31 & 60 & 2,94 & 0,50 & 1,98 & 7,23 \\
\hline Campomanesia velutina & 6 & 0,64 & 20 & 0,77 & 0,07 & 0,33 & 1,74 & - & - & - & - & - & - & - \\
\hline Ceiba pubiflora & 2 & 0,21 & 20 & 0,77 & 0,15 & 0,70 & 1,68 & - & - & - & - & - & - & - \\
\hline Terminalia glabrescens & 6 & 0,64 & 20 & 0,77 & 0,05 & 0,23 & 1,64 & - & - & - & - & - & - & - \\
\hline Guarea guidonia & 4 & 0,43 & 20 & 0,77 & 0,09 & 0,40 & 1,59 & 14 & 2,31 & 40 & 1,96 & 0,16 & 0,65 & 4,92 \\
\hline Pouteria torta & 6 & 0,64 & 20 & 0,77 & 0,02 & 0,11 & 1,52 & 14 & 2,31 & 60 & 2,94 & 0,26 & 1,02 & 6,27 \\
\hline Magonia pubescens & 2 & 0,21 & 20 & 0,77 & 0,10 & 0,46 & 1,45 & - & - & - & - & - & - & - \\
\hline Xylopia aromatica & 4 & 0,43 & 20 & 0,77 & 0,04 & 0,17 & 1,37 & - & - & - & - & - & - & - \\
\hline Terminalia argentea & 4 & 0,43 & 20 & 0,77 & 0,03 & 0,15 & 1,35 & - & - & - & - & - & - & - \\
\hline Cecropia pachystakia & 2 & 0,21 & 20 & 0,77 & 0,02 & 0,11 & 1,10 & - & - & - & - & - & - & - \\
\hline Ocotea corymbosa & 2 & 0,21 & 20 & 0,77 & 0,01 & 0,06 & 1,04 & - & - & - & - & - & - & - \\
\hline Aspidosperma multiflorum & 2 & 0,21 & 20 & 0,77 & 0,01 & 0,05 & 1,03 & - & - & - & - & - & - & - \\
\hline
\end{tabular}

FLORESTA, Curitiba, PR, v. 46, n. 4, p. 499 - 508, out. / dez. 2016.

Pereira, I. S. et al.

ISSN eletrônico 1982-4688

DOI: $10.5380 /$ rf.v46i3.45277 


\begin{tabular}{|c|c|c|c|c|c|c|c|c|c|c|c|c|c|c|}
\hline Trichilia claussenii. & 2 & 0,21 & 20 & 0,77 & 0,01 & 0,04 & 1,03 & - & - & - & - & - & - & - \\
\hline Dilodendron bipinnatum & 2 & 0,21 & 20 & 0,77 & 0,00 & 0,02 & 1,00 & 6 & 0,99 & 60 & 2,94 & 0,12 & 0,48 & 4,42 \\
\hline Aspidosperma sp. & - & - & - & - & - & - & - & 10 & 1,65 & 40 & 1,96 & 0,63 & 2,51 & 6,12 \\
\hline Terminalia phaeocarpa & - & - & - & - & - & - & - & 12 & 1,98 & 40 & 1,96 & 0,09 & 0,37 & 4,31 \\
\hline $\begin{array}{l}\text { Anadenanthera } \\
\text { macrocarpa }\end{array}$ & - & - & - & - & - & - & - & 2 & 0,33 & 20 & 0,98 & 0,40 & 1,59 & 2,90 \\
\hline Cordia sellowiana & - & - & - & - & - & - & - & 6 & 0,99 & 20 & 0,98 & 0,18 & 0,71 & 2,68 \\
\hline Aspidosperma parvifolium & - & - & - & - & - & - & - & 4 & 0,66 & 20 & 0,98 & 0,15 & 0,60 & 2,24 \\
\hline $\begin{array}{l}\text { Aspidosperma } \\
\text { macrocarpon }\end{array}$ & - & - & - & - & - & - & - & 2 & 0,33 & 20 & 0,98 & 0,19 & 0,74 & 2,05 \\
\hline Diospyros burchellii & - & - & - & - & - & - & - & 4 & 0,66 & 20 & 0,98 & 0,10 & 0,40 & 2,04 \\
\hline Triplaris americana & - & - & - & - & - & - & - & 4 & 0,66 & 20 & 0,98 & 0,08 & 0,34 & 1,98 \\
\hline Handroanthus ochraceus & - & - & - & - & - & - & - & 4 & 0,66 & 20 & 0,98 & 0,06 & 0,24 & 1,88 \\
\hline Vochysia tucanorum & - & - & - & - & - & - & - & 4 & 0,66 & 20 & 0,98 & 0,05 & 0,21 & 1,85 \\
\hline Attalea phalerata & - & - & - & - & - & - & - & 4 & 0,66 & 20 & 0,98 & 0,05 & 0,19 & 1,83 \\
\hline Xylopia emarginata & - & - & - & - & - & - & - & 4 & 0,66 & 20 & 0,98 & 0,03 & 0,12 & 1,76 \\
\hline Plenckia populnea & - & - & - & - & - & - & - & 4 & 0,66 & 20 & 0,98 & 0,03 & 0,12 & 1,76 \\
\hline Tibouchina candolleana & - & - & - & - & - & - & - & 4 & 0,66 & 20 & 0,98 & 0,01 & 0,05 & 1,69 \\
\hline Agonandra brasiliensis & - & - & - & - & - & - & - & 2 & 0,33 & 20 & 0,98 & 0,02 & 0,08 & 1,39 \\
\hline Rhamnidium elaeocarpum & - & - & - & - & - & - & - & 2 & 0,33 & 20 & 0,98 & 0,01 & 0,05 & 1,36 \\
\hline Total & 936 & 100 & 2600 & 100 & 21,4 & 100 & 300 & 606 & 100 & 2040 & 100 & 25,2 & 100 & 300 \\
\hline
\end{tabular}

Subtitle: $\mathrm{AD}=$ Absolute density; $\mathrm{RD}=$ Relative density, $\mathrm{AF}=$ Absolute frequency, $\mathrm{RF}=$ Relative frequency, $\mathrm{ADo}=\mathrm{Absolute}$ dominance, $\mathrm{RDo}=$ Relative Dominance and IVI = Importance Value Index.

The species Bowdichia virgilioides, Casearia silvestres, Tapirira guianensis, Zanthoxylum rhoifolium, Piptadenia gonoacantha, Acosmium subincanum, Myrcia rostrata, Luehea divaricata, Schefflera morototoni, Emmotum nitens, Guazuma ulmifolia., Tabebuia roseoalba, Handroanthus serratifolia, M. acutifolium and Protium heptaphyllum were associated with the unburned area (UB), with a higher occurrence in this area than in the B area (Figure 3). The burned area (B) was more related with the species H. courbaril, I. cylindrica, A. fraxinifolium, P. elegans, O. spixiana, X.sericea, C. estrellensis, and C. langsdorffii, which had a higher occurrence in this area. The species M. urundeuva and A. colubrina had a great relation both areas (Figure 3).

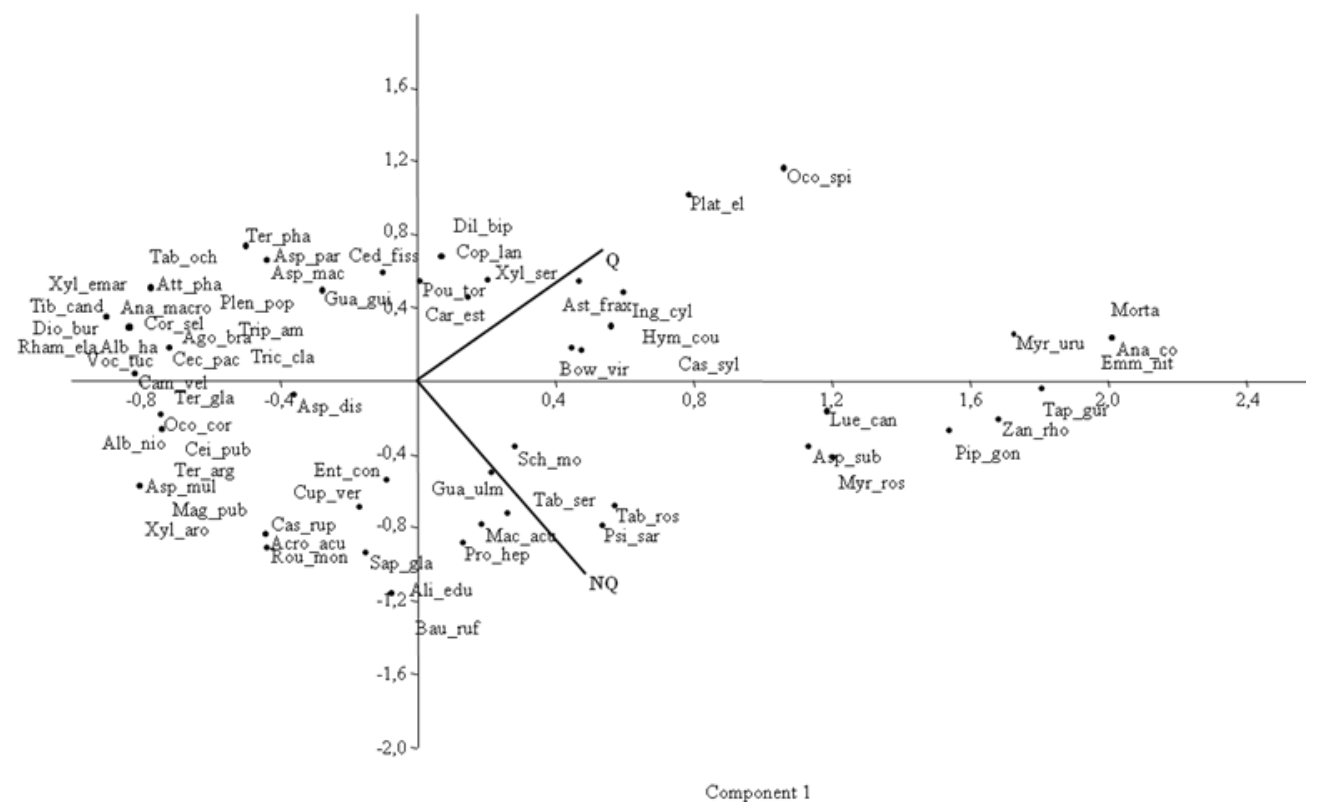

Figure 3. Principal components analysis of the occurrence of tree species in the two areas analyzed, burned (Q) and unburned (NQ) areas, considering fragments of the Seasonal Semideciduous Forest of the Altamiro de Moura Pacheco State park (AMPSP), Goiás.

Figura 3. Análise de componentes principais da ocorrência de espécies arbóreas nas duas áreas analisadas, queimado (Q) e áreas não queimadas (NQ), considerando fragmentos da Floresta Estacional Semidecidual do Parque Estadual Altamiro Moura Pacheco Moura (PEAMP), Goiás. 


\section{DISCUSSION}

The relative amount of dead tree trunks in the unburned area (UB) is similar to the observed for Brazilian forest formations with $7.29 \%$. In the burned area the number of dead trees reaches $12.69 \%$. The Family Fabaceae had the highest occurrence in both areas. This Family has important species for the ecological succession of a forest, given its primary function in nitrogen fixation (GUSSON et al, 2009). Pioneer species were recorded (highlighting $P$. gonoacantha), in addition to late secondary species (A. colubrina, Copaifera langsdorffii and Hymenaea courbaril).

The number of families recorded in the entire area was similar to the reported by Haidar (2008) in seasonal semideciduous forest fragments (SSFF) in Distrito Federal, and lower than the encountered by different authors in the same vegetation type in different regions of Brazil. The total basal area of $23.18 \mathrm{~m}^{2} . \mathrm{ha}^{-1}$, is similar to that of other studies in seasonal semideciduous forest in central Brazil. However, the tree density per hectare was lower than the values recorded by different authors (IMAÑA-ENCINAS et al., 2007; HAIDAR, 2008).

The genus Aspidosperma had the second largest species richness (five species). Aspidosperma species are heavily exploited due to good quality wood and have currently become rare due to the intense exploitation to which individuals were submitted to, in addition to deforestation (INSTITUTO BRASILEIRO DE GEOGRAFIA E ESTATÍSTICA (IBGE), 2002). Several genera of interest for the logging industry were also sampled, for example Tabebuia, Handroanthus, Myracrodruon, Hymenaea, Anadenanthera and Cedrella.

The occurrence of such genera shows the importance of maintaining the AMPSP, which functions as a gene bank (germplasm) of species threatened by exploitation without proper management or by the human pressure on natural communities (IBGE, 2002; HAIDAR, 2008). The ten species with the highest importance value indices (IVI) in the UB were, in a descending order: Anadenanthera colubrina (Vell.) Brenan, P. gonoacantha (Mart.), Emmotum nitens (Benth), Z. rhoifolium Lam., M. rostrata DC., Tapirira guianensis Aubl., Myracrodruon urundeuva Alemmão, Aspidosperma subincanum Mart ex DC., Luehea divaricata Mart. and Psidium sartorianum (O.Berg) Nied. These species add up to 55\% of the total IVI recorded for this tree community.

A higher concentration of individuals was recorded in the smaller diameter classes (DBH $>5 \leq 10 \mathrm{~cm}$ ), which is considered normal for Brazilian rainforests (MACHADO et al., 2010; SOUZA, 2012). However, the number of individuals in the smaller size class differs between the areas, where the burned area has fewer individuals than the unburned areas. This difference could be due to the action of fire during forest fire occurred because the effects of the flames are higher in smaller trees (RIBEIRO et al, 2012), leading therefore to a reduced density patches of smaller diameter in the burned area.

The fire in the burned area also affected harshly the trees in the larger diameter classes, showing that species of the seasonal semideciduous forests are more susceptible to the passage of fire, in contrast with species occurring in the savanna vegetation types. The basal area occupied by dead trees in the B area was $3.20 \mathrm{~m}^{2} / \mathrm{ha}$ while in the UB area was $1.20 \mathrm{~m}^{2} \mathrm{ha}^{-1}$. The B area had 72 ind.ha ${ }^{-1}$ and UB area had 74 ind.ha ${ }^{-1}$. The diameter distribution in both areas indicates that new individuals are entering the forest community. Self-regeneration of individuals in the burned area (B), may be inferred once the diameter distribution had an "inverted J" shape, which is typical of a largest number of individuals occurring in the smaller diameter classes (MARTINS et al., 2016).

The burned area (B) had density of individuals ranging from 51 to 91 individuals per plot while the unburned area (UB) had a variation of 74 to 119 individuals per plot. Therefore, burned area (B) had a density of individuals $36 \%$ lower than the unburned area (UB). The effect of fire modified the height distribution within the fragment, what affected light entrance. The light input may have been a determining factor for a greater occurrence of lianas and species of exotic grasses with invasive characteristics in the burned área. Lianas and invasive exotic grasses are mainly heliophytic and proliferate very effectively in illuminated environments (SILVA-NETO et al., 2015; VENTUROLI et al., 2015).

\section{CONCLUSION}

- The fire acted more severely on the smaller diameter classes, changing the density of individuals and the distribution among height classes. The fire also affected the trees in the larger diameter classes, showing the fragility of the species of this vegetation type in regards to forest fires.

- The clearings formed by the death and fall of the tree component in the burned area enabled a higher occurrence of colonizing species, especially lianas and grasses. Such higher occurrence changes the natural structural characteristics of the seasonal semideciduous forest fragments of the AMPSP. 


\section{REFERENCES}

APG III. Angiosperm Phylogeny Group III. An update of the Angiosperm Phylogeny Group classification for the orders and familyes of flowering plants: APG III. Botanical Journal of the Linnean Society, London, v. 161, p. 105-121, 2009.

CARDOSO, M. R. D.; MARCUZZO, F. F. N.; BARROS, J. R. Classificação Climática de Köppen-Geiger para o Estado de Goiás e o Distrito Federal. Acta Geografica, Boa Vista, v. 8, n. 16, p. 40-55, 2015.

COCHRANE, M. A.; SCHULZE, M. D. Fire as a recurrent event in tropical forest of the eastern Amazon: effects on forest structure, biomass, and species composition. Biotropica, Washington, v. 31, n. 1, p. 2-16, 1999.

EMPRESA BRASILEIRA DE PESQUISA AGROPECUÁRIA (EMBRAPA). Centro Nacional de Pesquisa de Solos. Sistema Brasileiro de Classificação de Solos. 3 ed. rev. ampl.- Brasília, DF: Embrapa, p. 353, 2013.

FELFILI, J. M.; FILGUEIRAS, T. S.; HARIDASAN, M.; SILVA-JÚNIOR, M. C.; MENDONÇA, R.; REZENDE, A. V. Projeto biogeografia do bioma cerrado: Vegetação e solos. Caderno de Geociências, Salvador, v. 12, p. 75-166, 1994.

FREIRE, S.; CARRÃO, H.; CAETANO, M. R. Produção de cartografia de risco de incêndio florestal com recurso a imagens de satélite e dados auxiliares. Instituto Geográfico Português, Lisboa, Portugal, 2002.

GUSSON, A. E.; LOPES, S. F.; DIAS-NETO, O. C.; VALE, V. S.; OLIVEIRA, A. P.; SCHIAVINI, I. Características químicas do solo e estrutura de um fragmento de floresta estacional semidecidual em Ipiaçu, Minas Gerais, Brasil. Rodriguesia, Rio de Janeiro, v. 60, n. 2, p. 403-414, 2009.

HAIDAR, R. F. Fitossociologia, diversidade e sua relação com variáveis ambientais em florestas estacionais do bioma cerrado no Planalto Central e Nordeste do Brasil. Dissertação de Mestrado. Universidade de Brasília. Brasília, DF. p. 254, 2008.

INSTITUTO BRASILEIRO DE GEOGRAFIA E ESTATÍSTICA (IBGE). Árvores do Brasil Central: espécies da região geoeconômica de Brasília. Diretoria de Geociências - Rio de Janeiro. v. 3, 2002.

IMAÑA-ENCINAS, J.; MACEDO, L. A.; PAULA, J. E. Florística e fitossociologia de um trecho de floresta estacional semidecidual na área do ecomuseu do Cerrado em Pirenópolis - Goiás. Cerne, Lavras, v. 13, p. 308320, 2007.

LIMA, E. S.; LIMA, H. S.; RATTER, J. A. Mudanças pós-fogo na estrutura e composição da vegetação lenhosa em um cerrado mesotrófico no período de cinco anos (1997-2002) em Nova Xavantina - MT. Cerne, Lavras, v. 15, p. 468-480, 2009.

LOPES, S. F.; VALE, V. S.; SCHIAVINI, I. Efeito de Queimadas Sobre a Estrutura e Composição da Comunidade Vegetal Lenhosa do Cerrado Sentido Restrito em Caldas Novas, GO. Revista Árvore, Viçosa, v. 33, n. 4, p. 695-704, 2009.

MACHADO, E. L. M.; GONGAZA, A. P. D.; AUGUSTO, W.; CARVALHO, C.; SOUZA, J. S.; HIGUCHI, P.; SANTOS, R. M.; SILVA, A. C.; OLIVEIRA-FILHO, A. T. Flutuações temporais nos padrões de distribuição diamétrica da comunidade arbóreo-arbustivo e de 15 populações em um fragmento florestal. Revista Árvore, Viçosa, v. 34, n. 4, p. 723-732, 2010.

MARTINS, T. O.; SOUZA, K. R.; OLIVEIRA, F. D.; SILVA-NETO, C. M.; VENTUROLI, F. Por trás das árvores comuns: padrões ambientais de arbóreas menos frequêntes na floresta estacional do Cerrado. TreeDimensional, Goiânia, v. 1, p. 42-55, 2016.

MINISTÉRIO DO MEIO AMBIENTE (MMA). Plano de Ação para prevenção e controle do desmatamento e das queimadas no Cerrado (PPCerrado): $2^{\mathbf{a}}$ fase. Brasília: MMA, p. 132, 2014.

PEEL, M. C.; FINLAYSON, B. L.; MCMAHON, T. A. Updated world map of the Köppen-Geiger climate classification. Hydrology and Earth System Sciences, v. 11, p. 1633-1644. 2007.

RIBEIRO, J. F.; WALTER, B. M. T. As principais fitofisionomias do Bioma Cerrado. In: SANO, S. M.; ALMEIDA, S. P.; RIBEIRO, J. F. Cerrado: Ecologia e Flora. Brasília: EMBRAPA, p. 152-212, 2008.

RIBEIRO, M. N.; SANCHEZ, M.; PEDRONI, F.; PEIXOTO, K. Fogo e dinâmica da comunidade lenhosa em cerrado sentido restrito, Barra do Garças, Mato Grosso. Acta Botanica Brasilica, Belo Horizonte, v. 26, n. 1, p. 203-217, 2012.

SECRETARIA ESTADUAL DE MEIO AMBIENTE E RECURSOS HÍDRICOS DO ESTADO DE GOIÁS 
(SEMARH). Inventário de Flora do Parque Ecológico Altamiro de Moura Pacheco e Parque dos Ipês. Goiás. Available in:< http://www.semarh.goias.gov.br/site/uploads/files/invent\%C3\%A1rio_de_florapeamp.pdf $>$. Access in: February 2015.

SILVA-NETO, C. M.; VENTUROLI, F.; GONCALVES, B. B.; FERREIRA, G. A. Incremento diamétrico de Protium heptaphyllum (Aubl.) Marchand em Floresta estacional semidecídua sob manejo, em Pirenópolis, Goiás. Interciência, Caracas, v. 40, p. 564-569, 2015.

SIMON, M. F.; GRETHER, R.; QUEIROZ, L. P.; SKEMA, C.; PENNINGTON, R. T.; HUGHES, C. E. Recent assembly of the Cerrado, a Neotropical plant diversity hotspot, by in situ evolution of adaptations to fire. Proceedings of the National Academy of Science, London, v. 106, n. 48, p. 20359-20364, 2009.

SOUZA, P. B.; SOUZA, A. L.; MEIRA-NETO, J. A. A. Estrutura diamétrica dos estratos e grupos ecológicos de uma área de Floresta Estacional Semidecidual em Dionísio, MG. Revista Árvore, Viçosa, v. 36, n. 1, p. 151160, 2012.

TORRES, F. T. P. Relações entre fatores climáticos e ocorrências de incêndios florestais na cidade de Juiz de Fora (MG). Caminhos de Geografia, Uberlândia, v. 7 n. 18, p. 162-171, 2006.

VENTUROLI, F.; CARVALHO, F. A.; SILVA-NETO, C. M.; MORAES, D. C.; MARTINS, T. O.; SOUZA, D. M. Manejo Florestal no bioma Cerrado: uma opção para conservar e lucrar. Scientia Forestalis, Piracicaba, v. 35, p. 1-10, 2015.

VENTUROLI, F.; MARTINS, T. O.; SILVA-NETO, C. M. Diversidade de critérios e uniformidade de indicadores na amostragem de Cerrado. TreeDimensional, Goiânia, v. 1, p. 29-41, 2016. 